\title{
Pengaruh Strategi Promosi Melalui Media Sosial, Kualitas Pelayanan, dan Word of Mouth Terhadap Loyalitas Pelanggan pada Warung Kopi Cak Kebo
} (The Effect of Promotion Strategy Through Social Media, Quality of Service, and Word of Mouth on Customer Loyalty in Cak Kebo Coffee Store)

\author{
Mochtar Luthfi Effendy*, Maheni Ika Sari, Haris Hermawan \\ Universitas Muhammadiyah Jember \\ Jl. Karimata No. 49 Jember, Jawa Timur, Indonesia \\ Email: mochtarluthfieffendy@gmail.com
}

\begin{abstract}
Abstrak
Penelitian dilakukan pada pelanggan warung kopi Cak Kebo Jember dengan bertujuan untuk mengetahui dan menganalisis pengaruh strategi promosi melalui media sosial, kualitas pelayan, dan word of mouth terhadap loyalitas pelanggan. Penelitian ini menggunakan jenis penelitian deskriptif kuantitatif dengan menggunakan metode purposive sampling dengan sampel seratus orang responden. Alat uji yang digunakan adalah regresi linier berganda, dengan perangkat lunak SPSS versi 25 sebagai alat bantu perhitungan. Hasil penelitian menunjukkan variabel kualitas pelayan dan word of mouth memiliki nilai positif dan signifikan mempengaruhi loyalitas pelanggan yang berarti semakin baik kualitas pelayan dan word of mouth akan berdampak pada semakin baiknya loyalitas pelanggan, sedangkan strategi promosi melalui media sosial memiliki pengaruh negatif dan tidak signifikan dalam mempengaruhi loyalitas pelanggan. Sebaiknya warung kopi Cak Kebo lebih memfokuskan pada promosi dengan word of mouth. Pendekatan melalui organisasi dan kelompok mahasiswa sebagai agen utama penyebaran word of mouth serta dengan media sosial sebagai alat pedukung, akan lebih berdampak langsung pada pengembangan usaha sehingga lebih menarik perhatian pelanggan baru dan dapat meningkatkan minat pelanggan berkunjung kembali sehingga memperoleh hasil yang lebih baik lagi.
\end{abstract}

Kata Kunci: Strategi Promosi Melalui Media Sosial, Kualitas Pelayan, Word of Mouth, dan Loyalitas Pelanggan..

\begin{abstract}
The study aims to determine and analyze the influence of promotional strategies through social media, the quality of waiters, and word of mouth on customer loyalty of Cak Kebo coffee shop customers in Jember. This study used quantitative descriptive research using the purposive sampling method with a sample of one hundred respondents. The multiple linear regression, with SPSS version 25, was applied to analyze the data. The results showed that the variable quality of waiters and word of mouth has a positive and significantly affects customer loyalty which means the better the quality of the waiter and word of mouth, the better customer loyalty. In contrast, promotional strategies through social media had a negative and insignificant influence on the customer loyalty. Coffee shops should focus more on word of mouth promotion. Organizations and student groups, as the main agent of word of mouth dissemination, should be approached. Meanwhile, the role of social media as a support tool should be improved to attract new customers and increase customer repurchase intention.
\end{abstract}

Keywords: Customer Loyalty, Social Media Promotion, Service Quality, Word of Mouth.

\section{Pendahuluan}

Sesuai hasil yang disampaikan oleh International Coffee Organization (ICO), tingkat komsumsi kopi di Indonesia telah meningkat sebesar $1,7 \%$ selama 4 tahun terakhir. Informasi ini membuat bisnis warung kopi dan cafe seolah-olah memiliki peluang besar, tetapi ada juga banyak restoran yang mengalami kesulitan karena tidak dapat mengikuti dan menambah jumlah pelanggan. Sebagai salah satu poin dari periklanan, promosi adalah cara yang tepat untuk membuat organisasi semakin dikenal luas. Melalui periklanan, sebuah usaha dapat

* Corresponding Author memperluas kontribusi mereka pada item yang mereka hasilkan. Word of Mouth (WOM) adalah salah satu cara promosi melalui lisan secara langsung yang mempengaruhi seseorang karena data yang diperoleh dianggap benar dan adil dan seseorang pada umumnya. Pelanggan akan mempercayai data produk yang mereka dengar dari teman, anggota keluarga atau orang terdekat yang memiliki wawasan dengan produk daripada yang mereka lakukan dengan data dari iklan.

Ketika konsumen sudah menggunakan sebuah produk, konsumen akan melakukan penilaian terhadap produk yang telah dikonsumsinya, apabila produk tersebut memberikan kepuasan dan kesan positif kepada 
konsumen, maka word of mouth positif yang kemungkinan akan terjadi, begitu pula sebaliknya akan bersifat negatif ketika konsumen tidak merasa puas dan mempunyai kesan negatif terhadap produk yang dipakainya. Terjadinya word of mouth memicu calon konsumen baru untuk melakukan pembelian dalam sebuah produk yang telah didengarnya dari orang lain. Ketika calon konsumen sudah mengetahui tentang produk yang telah ditawarkan melalui promosi maupun mendapatkan informasi dari mulut ke mulut, maka calon konsumen berhak melakukan pertimbangan sebelum mereka memutuskan sebuah keputusan dalam pembelian.

Kabupaten Jember sebagai salah satu kota pelajar, menjadi kota tujuan perantauan bagi kota-kota lain disekitar. Adanya beberapa sekolah dan perguruan tinggi seperti Universitas Jember dan Universitas Muhammadiyah Jember, membuat Kota Jember membuka peluang besar bagi pembisnis yang menargetkan pelajar dan mahasiswa. Salah satunya adalah warung kopi Cak Kebo.

Kebiasaan minum kopi pada mahasiswa telah membentuk sebuah tren baru terkait kebiasaan. Budaya ini menjadi dasar berdirinya warung kopi Cak Kebo pada tahun 2016. Konsep yang digunakan berupa warung kopi yang dapat digunakan sebagai ruang diskusi untuk pelanggan yang mayoritas adalah mahasiswa dengan penambahan fasilitas berupa wifi sebagai pendukung. Dengan konsep sebagai sebagai tempat untuk berdiskusi, warung kopi Cak Kebo dilengkapi dengan sebuah mini perpustaan yang memuat beberapa buku terkait politik. Ada juga jenis buku bacaan ringan seperti novel yang dapat diakses untuk pengunjung warung.

Pada awal pendirian, warung kopi Cak Kebo ini menggandeng organisasi mahasiswa sebagai media promosi. dengan tempat yang memadai untuk berdiskusi, warung ini menjadi tempat untuk para mahasiswa yang tergabung organisasi melakukan rapat, walaupun intensitas tidak terlalu sering.

Penelitian ini bertujuan untuk mengetahui pengaruh strategi promosi melalui media sosial terhadap loyalitas pelanggan untuk pelanggan di warung kopi Cak Kebo, untuk mengetahui pengaruh kualitas pelayan terhadap loyalitas pelanggan untuk pelanggan di warung kopi Cak Kebo, dan untuk mengetahui pengaruh word of mouth terhadap loyalitas pelanggan untuk pelanggan di warung kopi Cak Kebo.

Menurut hasil pada observasi awal dengan mewawancarai 20 orang pelanggan secara acak, penggunaan sosial media sebagai media promosi masih kurang optimal. Ini dilihat dari kontribusi sosial media untuk memikat pelanggan total hanya sekitar $15 \%$ atau 3 orang. Sedangkan untuk sisanya sebanyak 13 orang atau $65 \%$ berasal dari kemampuan word of mouth pelanggan untuk merekomendasikan pada konsumen baru. Selain itu sebesar $20 \%$ atau 4 orang konsumen datang dikarenakan posisi warung yang berada di pinggir jalan.

Dari tabel 1 terlihat sejak pemberlakuan sistem new normal, pedapatan warung kopi Cak Kebo merugi. Hasil wawancara peneliti dengan pemilik saat observasi awal pada tanggal 10 Oktober 2020, mendapatkan bahwa omzet warung kopi Cak Kebo menurun sebesar 50\% dari pada hari biasa. Hal ini terjadi dikarenakan para mahasiswa yang menjadi salah satu target pasar warung kopi Cak Kebo, sedang pulang kampung. Penyebab ini juga terjadi pada saat masa liburan semester, akan tetapi dampak tidak sebesar pada saat new normal pasca pandemi. Dari penjelasan tersebut, didapat hipotesa berupa strategi promosi melalui media sosial berpengaruh signifikan terhadap loyalitas pelanggan untuk pelanggan di warung kopi Cak Kebo.

Tabel 1. Rekap Omzet Per Minggu Warung Kopi Cak Kebo

\begin{tabular}{|c|c|c|}
\hline \\
\hline Bulan / Pekan & Omze & \\
\hline Juni Pekan 3 & $\mathrm{Rp}$ & $4,050,000$ \\
\hline Juni Pekan 4 & $\mathrm{Rp}$ & $4,750,000$ \\
\hline Juli Pekan 1 & $\mathrm{Rp}$ & $4,200,000$ \\
\hline Juli Pekan 2 & $\mathrm{Rp}$ & $5,200,000$ \\
\hline Juli Pekan 3 & $\mathrm{Rp}$ & $4,850,000$ \\
\hline Juli Pekan 4 & $\mathrm{Rp}$ & $5,500,000$ \\
\hline Juli Pekan 5 & $\mathrm{Rp}$ & $5,200,000$ \\
\hline Agustus Pekan 1 & $\mathrm{Rp}$ & $6,700,000$ \\
\hline Agustus Pekan 2 & $\mathrm{Rp}$ & $4,800,000$ \\
\hline Agustus Pekan 3 & $\mathrm{Rp}$ & $4,600,000$ \\
\hline Agustus Pekan 4 & $\mathrm{Rp}$ & $5,950,000$ \\
\hline September Pekan 1 & $\mathrm{Rp}$ & $5,700,000$ \\
\hline September Pekan 2 & $\mathrm{Rp}$ & $6,250,000$ \\
\hline September Pekan 3 & $\mathrm{Rp}$ & $5,450,000$ \\
\hline September Pekan 4 & $\mathrm{Rp}$ & $4,150,000$ \\
\hline Oktober Pekan 1 & $\mathrm{Rp}$ & $6,000,000$ \\
\hline Oktober Pekan 2 & $\mathrm{Rp}$ & $6,440,000$ \\
\hline Oktober Pekan 3 & $\mathrm{Rp}$ & $6,800,000$ \\
\hline Oktober Pekan 4 & $\mathrm{Rp}$ & $5,900,000$ \\
\hline Oktober Pekan 5 & $\mathrm{Rp}$ & $6,300,000$ \\
\hline
\end{tabular}

Sumber : Data Primer, 2020

Dalam peningkatan optimasi sosial media yang telah dilakukan pemilik warung yaitu berupa pemanfaatan para karyawan sebagai agen promosi di media sosial hanya mampu mendatangkan beberapa pelanggan pada hari-hari tertentu saja. Selain strategi promosi, kualitas pelayanan merupakan aspek penting dalam mewujudkan loyalitas pelanggan. Saat ini, warung kopi Cak Kebo telah meningkatkan sarana dan prasarana telah dilakukan berupa penambahan kamar mandi, gazebo, dan menu dirasa belum optimal. Penambahan sejumlah menu baru telah diterapkan untuk menambah variasi. Selain dari sarana dan menu, pembentukan ruang diskusi untuk para pelajar dan mahasiswa dan difasilitasi dengan pembuatan perpustakaan mini. Fasilitas ini dapat digunakan oleh pelajar atau mahasiswa sebagai bahan referensi untuk diskusi atau membaca. Berdasarkan penjelasan tersebut, dirumuskan hipotesa berupa kualitas pelayan berpengaruh signifikan terhadap loyalitas pelanggan untuk pelanggan di warung kopi Cak Kebo 
Berdasarkan latar belakang diatas, maka identifikasi masalah dalam penelitian ini adalah:

1. Apakah strategi promosi melalui media sosial berpengaruh terhadap loyalitas pelanggan untuk pelanggan di warung kopi Cak Kebo?

2. Apakah kualitas pelayan berpengaruh terhadap loyalitas pelanggan untuk pelanggan di warung kopi Cak Kebo?

3. Apakah word of mouth berpengaruh terhadap loyalitas pelanggan untuk pelanggan di warung kopi Cak Kebo?

\section{Kajian Teori}

\section{Manajemen Pemasaran}

Menurut Kotler dan Keller (2012:146) mengungkapkan bahwa pengertian pemasaran adalah proses dimana perusahaan menciptakan nilai bagi pelanggan dan membangun hubungan yang kuat dengan pelanggan untuk menangkap nilai yang baik dari pelanggan sebagai imbalannya.

Dengan definisi seperti tersebut di atas, maka 3 (tiga) hal yang merupakan unsur pokok konsep pemasaran dapat disebutkan yaitu (Swasta dan Handoko, 1997):

a Orientasi pada konsumen atau pasar atau pembeli. Perusahaan yang benar- benar ingin memperhatikan konsumen harus

1. Menentukan kebutuhan pokok (basic needs) dari pembeli yang akan dilayani dan dipenuhi

2. Menentukan kelompok pembeli yang akan dijadikan sasaran penjualan

3. Menentukan produk dan program pemasarannya.

4. Mengadakan penelitian pada konsumen, untuk mengukur, menilai, dan menafsirkan keinginan, sikap, serta perilaku mereka.

5. Menentukan dan melaksanakan strategi yang paling baik, apakah menitikberatkan pada mutu yang tinggi, harga yang murah atau model yang menarik.

b. Volume penjualan yang menguntungkan. Merupakan tujuan dari konsep pemasaran, laba itu dapat diperoleh dengan melalui pemasaran konsumen. Dengan laba ini, perusahaan dapat tumbuh dan berkembang dengan menggunakan kemampuan yang lebih besar, dapat memberikan tingkat kepuasan yang lebih besar pada konsumen.

c. Penyusunan kegiatan pemasaran secara integral (integrated marketing). Pengintegrasian kegiatan pemasaran berarti bahwa setiap orang dan setiap bagian dalam perusahaan turut berkecimpung dalam suatu usaha yang terkoordinir untuk memberikan kepuasan konsumen, sehingga tujuan perusahaan dapat direalisir.

\section{Pengertian Promosi}

Promosi adalah suatu kegiatan yang bertujuan memperkenalkan produk baru yang dibuat oleh perusahaan dengan harapan konsumen akan tertarik dan akan membeli produk tersebut. Kegiatan ini merupakan proses penyebaran informasi yang tingkat kegencarannya tergantung pada besarnya dana promosi yang disediakan oleh perusahaan. Promosi adalah komunikasi dari para penjual yang menginformasikan, membujuk, dan mengingatkan para calon pembeli suatu produk dalam rangka mempengaruhi pendapat mereka atau memperoleh suatu respon.

Promosi merupakan kegiatan yang berperan aktif dalam memperkenalkan, memberitahukan dan mengingatkan kembali manfaat duatu produk agar mendorong konsumen untuk membeli produk yang dipromosikan tersebut. Setiap perusahaan harus dapat menentukan dengan tepat alat promosi manakah yang dipergunakan agar dapat mencapai keberhasilan dalam penjualan. Promosi juga salah satu faktor penentu keberhasilan suatu program pemasaran. Betapapun berkualitasnya suatu produk, apabila konsumen belum pernah mendengarnya dan tidak yakin bahwa produk tersebut akan berguna bagi mereka, maka mereka tidak akan pernah membelinya.

\section{Tujuan Promosi}

Promosi menunjuk pada berbagai aktivitas yang dilakukan perusahaan untuk mengkomunikasikan kebaikan produknya dan membujuk para pelanggan dan konsumen sasaran untuk membeli produk tersebut. Sehingga promosi merupakan suatu dasar kegiatan komunikasi perusahaan dengan konsumen untuk mendorong terciptanya penjualan. Dalam praktiknya promosi dapat dilakukan dengan mendasar pada tujuan-tujuan sebagai berikut:

a. Modifikasi tingkah laku

Promosi berusaha untuk merubah tingkah laku dan pendapat serta memperkuat tingkah laku yang ada.

b. Memberitahu

Kegiatan promosi itu dapat ditujukan untuk memberitahu pasar yang dituju tentang penawaran perusahaan.

c. Membujuk

Promosi mengutamakan memberi bujukan untuk mendorong pembelian pelanggan. Sering perusahaan tidak ingin memperoleh tanggapan secepatnya tetapi lebih mengutamakan untuk menciptakan kesan positif. Hal ini dimaksudkan agar dapat memberi pengaruh dalam waktu yang lama terhadap perilaku pembeli.

d. Mengingatkan

Promosi yang bersifat mengingatkan dilakukan terutama untuk mempertahankan merk produk di hati masyarakat dan perlu dilakukan selama tahap kedewasaan di dalam siklus kehidupan produk. Ini berarti perusahaan berusaha untuk paling tidak mempertahankan pembeli yang ada.

\section{Strategi Promosi}

Strategi promosi menurut Menurut Kotler dan Keller (2009:138) adalah kreativitas mengkomunikasikan keunggulan produk serta membujuk pasar sasaran. Menurut Kotler (dalam Kendri, 2018), ada beberapa hal 
yang perlu diperhatikan dalam mengembangkan promosi terintegrasi untuk mencapai strategi promosi yang efektif, antara lain :

a. Jangkauan promosi

Persentase audiens sasaran yang diekspos sekurangkurangnya satu kali dengan pesan pemasang iklan selama jangka waktu tertentu.

b. Kuantitas penayangan iklan di media promosi Jumlah waktu rata-rata, dalam periode empat minggu di mana para anggota audiens sasaran diekspos kepada sarana media yang termasuk dalam jadwal media tertentu.

c. Kualitas penyampaian pesan dalam penayangan iklan di media promosi

Maksud, tujuan, dan informasi yang ingin disampaikan dalam penayangan iklan produk

\section{Kualitas Pelayanan}

Pelayanan adalah segala kegiatan atau tindakan yang dapat dihadirkan oleh suatu pihak kepada pihak lain yang pada dasarnya bersifat teoritis dan tidak menimbulkan tanggung jawab Kotler dan Keller (2009:138). Penciptaannya mungkin terhubung ke item produk yang sebenarnya. Pelayanan adalah perilaku pembuat untuk mengatasi masalah dan keinginan pelanggan untuk mencapai pemenuhan bagi pembeli yang sebenarnya. Saat ini, perusahaan tidak hanya bersaing dengan biaya, tetapi perusahaan harus dapat mengembangkan teknik untuk menawarkan jenis bantuan kepada pelanggan, terutama yang mempengaruhi produk dan layanan.

Pelayanan yang bagus adalah wawasan yang diperoleh pembeli dengan mengandalkan asumsi mereka (Cook 2004:16). Jika pelayanan yang didapat pembeli ternyata sangat baik, dipandang sebagai pelayanan yang berkualitas dan baik. Tetepi, jika pelayanan yang didapat pembeli tidak sesuai dengan yang diharapkan, maka akan dianggap sebagai jasa yang buruk. Cara untuk mengetahui kualitas pelayanan adalah dengan membandingkan pandangan pembeli dan administrasi yang benar-benar diperoleh atau diperoleh pelanggan dengan administrasi biasa atau diinginkan pada kredit bantuan suatu organisasi. Perushaaan menganggap pelanggan sebagai tuan yang harus dilayani dengan baik karena mengingat pembeli ini akan memberikan keuntungan berkelanjutan bagi organisasi. Terdapat lima dimensi kualitas layanan yaitu tangible, reliability, responsiveness, assurance, dan emphaty.

\section{Word Of Mouth (WOM)}

Manuel Rosen (2000:7) berpendapat bahwa word of mouth adalah keseluruhan komunikasi dari orang ke orang mengenai suatu produk, jasa atau perusahan tertentupada suatu waktu. Bone (1992:579-583) mengemukakan, word of mouth adalah pertukaran komentar, pemikiran, atau ide-ide antara dua konsumen atau lebih, dimana tidak satu pun dari mereka adalah sumber pemasaran. Lebih jelas lagi semakin besar volume yang ada dan semakin luas dispersion yang ada, maka semakin besar adanya word of mouth dan begitu juga sebaliknya.

Menurut Kotler dan Keller (2007:204), saluran komunikasi personal yang berupa ucapan atau perkataan dari mulut ke mulut (word of mouth) dapat menjadi metode promosi yang efektif karena pada umumnya disampaikan dari konsumen oleh konsumen dan untuk konsumen, sehingga konsumen atau pelanggan yang puas dapat menjadi media iklan bagi perusahaan. Selain itu, menurut Kotler \& Keller (2007:204) saluran komunikasi personal word of mouth tidak membutuhkan biaya yang besar karena dengan melalui pelanggan yang puas, rujukan atau referensi terhadap produk hasil produksi perusahaan akan lebih mudah tersebar ke konsumenkonsumen lainnya. Menurut Lupiyoadi (2013:160), komunikasi word of mouth (WOM) dapat diukur dari kemampuan konsumen mendapatkan informasi tentang perusahaan, kemampuan konsumen terdorong untuk melakukan pembelian dikarenakan motivasi dari orang lain (menumbuhkan motivasi), dan kemampuan konsumen mendapatkan rekomendasi dari orang lain.

Komunikasi word of mouth memegang kunci utama dalam menciptakan loyalitas pelanggan dan tentu berbanding lurus dengan berjalannya suatu bisnis. Word of mouth dapat memunculkan konsumen baru untuk melakukan pembelian suatu produk atau jasa yang telah di rekomendasikan oleh orang lain. Seperti pada penelitian dari Dimas Kawa (2015) menunjukkan bahwa word of mouth sangat mempengaruhi loyalitas pelanggan kedepannya.

\section{Loyalitas Pelanggan}

Kewajiban klien terhadap merek yang bergantung pada pandangan yang sangat menggembirakan dan tercermin dalam pembelian berulang yang dapat diprediksi merupakan definisi dasar dari loyalitas pelanggan. Dalam pemasaran jasa, loyalitas pelanggan merurapakan hasil dari reaksi yang secara tegas diidentifikasikan dengan sumpah atau jaminan untuk mempertahankan tanggung jawab yang mendasari pengelolaan hubungan dan biasanya tercermin dalam pembelian tanpa henti dari organisasi spesialis serupa berdasarkan komitmen dan bahkan perintah yang berpikiran sama (Tjiptono 2012:482). Pelanggan setia adalah pelanggan yang sangat senang dengan produk atau layanan tertentu sehingga mereka memiliki energi untuk memperkenalkannya kepada siapa pun yang mereka kenal Griffin dalam Diah (2006:38).

Pembelian ulang dilakukan bukan karena terpenuhi tetapi mungkin karena dibatasi atau elemen lain yang dikeluarkan dari pengukuran khusus. Oleh karena itu, untuk melihat perilaku setia pengukuran ini dilihat dari adalah dari tanggung jawab pembelian berulang yang berfokus pada item dalam jangka waktu tertentu secara konsisten. Loyalitas pelanggan dapat dicirikan sebagai tujuan klien untuk memiliki pilihan untuk terus menggunakan administrasi koperasi spesialis tergantung pada pengalaman masa lalu dan asumsi masa depan. Indikator loyalitas pelanggan menurut Kotler \& Keller (2006:57) berupa repeat purchase/kesetiaan terhadap pembelian produk, retention/ketahanan terhadap pengaruh yang negatif mengenai perusahaan, dan refealls/mereferensikan secara total esistensi perusahaan. 


\section{Metode}

\section{Desain Penelitian}

Dalam penelitian ini, penulis menggunakan penelitian deskriptif, yaitu suatu metode penelitian yang menggambarkan karakteristik populasi atau fenomena yang sedang diteliti. Fokus utama adalah menjelaskan objek penelitiannya sehingga menjawab apa peristiwa atau apa fenomena yang terjadi. Penelitian ini dilakukan di warung kopi Cak Kebo Jember.

\section{Jenis Data}

Penelitian ini menggunakan data primer berupa hasil yang diperoleh dari penyebaran kuisioner yang disebarkan pada warung kopi Cak Kebo Jember.

\section{Populasi dan Sampel}

Penelitian ini menggunakan populasi yaitu pelanggan warung kopi Cak Kebo Jember dan Sampel dengan menggunakan metode adalah pengambilan sampel dengan metode purposive sampling dengan kriteria sebagai berikut:

a. Pelanggan warung kopi Cak Kebo ditandai dengan tingkat kedatangan minimal 3 kali dalam seminggu.

b. Masyarakat Jember atau orang yang perantauan yang tinggal di Kota Jember

c. Pelajar pekerja, atau mahasiswa yang sedang menempuh Pendidikan di salah satu sekolah, perguruan atau perusahaan di Kota Jember.

Jumlah sampel minimal yang dibutuhkan dalam penelitian ini adalah sejumlah 100 orang. Jumlah sampel ini berupa pembulatan dari 96, yang digunakan karena jumlah populasi yang diteliti tidak diketahui.

\section{Metode Analisis Data \\ Uji Instrument Data \\ Uji Validitas}

Uji validitas digunakan untuk mengukur valid atau tidaknya suatu indikator. Suatu kuisioner dikatakan valid jika pertanyaan kuisioner mampu untuk mengungkapkan sesuatu yang diukur oleh kuisioner tersebut. Dalam penelitian ini, validitas instrument penelitian dilakukan dengan melihat angka signifikasi yaitu membandingkan nilai $r$ hitung (corrected item-total correlation) dengan tabel untuk degree of freedom $(\mathrm{df})=\mathrm{n}-2$. Dan nilai signifikasi $<0,05$.

\section{Uji Reliabilitas}

Uji reliabilitas digunakan untuk mengukur kehandalan indikator. Jika angka reliabilitas Alpha Cronbach > 0,60 maka item variabel tersebut dinyatakan reliabel (Nunally dalam Ghozali, 2009:22).

\section{Analisis Regresi Linier Berganda}

Model regresi linier berganda adalah model yang digunakan untuk menganalisis pengaruh dari berbagai variabel independen terhadap satu variabel dependen. Rumus untuk regresi linear berganda adalah sebagai berikut:

$$
\text { Rumus }=\mathrm{Y}=\mathrm{a}+\mathrm{b} 1 \mathrm{X} 1+\mathrm{b} 2 \mathrm{X} 2+\mathrm{b} 3 \mathrm{X} 3+e
$$

Keterangan :

$\mathrm{Y}=$ Loyalitas Pelayanan

$\mathrm{a}=$ Konstanta

$\mathrm{X}_{1}=$ Varabel Strategi Promosi Melalui Media Sosial

$\mathrm{X}_{2}=$ Variabel Kualitas Pelayanan

$\mathrm{X}_{3}=$ Variabel Word of Mouth

$\mathrm{b}_{1}=$ Koefisien Regresi dari Strategi Promosi Melalui

Media Sosial

$\mathrm{b}_{2}=$ Koefisien Regresi dari Kualitas Pelayanan

$\mathrm{b}_{3}=$ Koefisien Regresi dari Word Of Mouth

$\mathrm{e}=$ Standard Error

\section{Uji Asumsi Klasik}

Uji Normalitas

Uji normalitas bertujuan untuk menguji apakah dalam model regresi, variabel pengganggu atau residual memiliki distribusi normal. Kita dapat melihatnya dari normal probability plot yang membandingkan distribusi kumulatif dengan distribusi normal. Distribusi normal membentuk suatu garis lurus diagonal, dan ploting data residual akan dibandingkan dengan garis diagonalnya. Jika distribusi data normal, maka garis yang menggambarkan data sebenarnya akan mengikut garis normalnya.

\section{Uji Multikolinearitas}

Uji multikolineritas bertujuan menguji apakah dalam model regresi ditemukan adanya korelasi antar variabel bebas model regresi yang baik seharusnya tidak terjadikorelasi diantara variabel bebas jika variabel bebas berkorelasi maka variable-variabel ini tidak ortogonal. Variabel ortogonal adalah variabel bebas yang nilai korelasi antar sesama variabel bebas $=0$. Multikolineritas dapat dilihat dari nilai Tolerance dan Variance Inflation Factor (VIF).

\section{Uji Heteroskedastisitas}

Uji heteroskedastisitas bertujuan apakah dalam model regresi ketidaksamaan variance dari residual satu pengamatan kepengamatan yang lain. Jika variance dari residual pengamatan yang lain tetap, disebut homoskedastisitas dan jika berbeda disebut heteroskedastisitas. Model regresi yang baik adalah homoskedastisitas atau tidak terjadi heteroskedastisitas.

\section{Pengujian Hipotesis (Uji t)}

Uji t adalah uji yang mengukur besarnya perbedaan dua atau beberapa mean antar kelompok. Uji t digunakan untuk menghitung signifikasi pengaruh secara parsial dari variabel. strategi promosi melalui media sosial, kualitas pelayanan, word of mouth layak untuk menjelaskan variabel dependennya, yaitu loyalitas pelanggan.

\section{Koefisien Determinasi $\left(\mathbf{R}^{\mathbf{2}}\right)$}

Koefisiensi determinasi (R2) pada intinya mengukur seberapa jauh kemampuan model dalam menerangkan variasi variabel dependen. Nilai koefisien determinasi adalah antara nol dan satu. Nilai R2 yang kecil berarti kemampuan variabel-variabel independen dalam menjelaskan variasi variabel dependen amat terbatas. 
Nilai yang mendekati satu berarti variabel-variabel independen memberikan hampir semua informasi yang dibutuhkan untuk memprediksi variasi variabel dependen (Ghozali, 2009:39).

\section{Hasil dan Pembahasan}

\section{Deskripsi Responden}

\section{Responden Berdasarkan Umur}

Berdasarkan data pada tabel 2, diketahui bahwa sebagian besar responden berasal dari berumur 21-24 tahun sebanyak 61 orang $(61 \%)$ dan tertinggi kedua kelompok umur 25-28 tahun sebayak 32 orang (32\%). Hal ini menunjukkan bahwa sebagian besar pelanggan warung kopi Cak Kebo adalah kelompok usia 21-24 tahun.

Tabel 2. Distribusi Frekuensi Umur

\begin{tabular}{cccc}
\hline No & Umur & $\begin{array}{c}\text { Jumlah } \\
\text { (orang) }\end{array}$ & $\begin{array}{c}\text { Presentase } \\
(\%)\end{array}$ \\
\hline 1 & $17-20$ tahun & 5 & 5 \\
2 & $21-24$ tahun & 61 & 61 \\
3 & $25-28$ tahun & 32 & 32 \\
4 & $29-32$ tahun & 2 & 2 \\
\hline & Jumlah & 100 & 100,0 \\
\hline
\end{tabular}

Sumber : Data primer, diolah tahun 2021

\section{Responden Berdasarkan Jenis Kelamin}

Berdasarkan kuesioner yang dibagikan kepada 100 pelanggan berdasarkan jenis kelamin laki-laki dan perempuan sebagai berikut:

Tabel 3. Distribusi Frekuensi Jenis Kelamin

\begin{tabular}{llcc}
\hline No & Jenis kelamin & $\begin{array}{c}\text { Jumlah } \\
\text { (orang) }\end{array}$ & $\begin{array}{c}\text { Presentase } \\
(\%)\end{array}$ \\
\hline 1 & Laki-laki & 75 & 75 \\
2 & Perempuan & 25 & 25 \\
\hline & Jumlah & 100 & 100 \\
\hline
\end{tabular}

Data primer, diolah tahun 2021

Sebanyak 75 responden berjenis kelamin laki-laki atau $75 \%$. warung kopi Cak Kebo cenderung yang membeli dan meminum kopi adalah laki-laki.

\section{Responden Berdasarkan Pekerjaan}

Berdasarkan kuesioner yang dibagikan kepada 100 pelanggan diperoleh data responden menurut pekerjaan sebagai berikut :

Tabel 4. Distribusi Frekuensi Pekerjaan

\begin{tabular}{clcc}
\hline No & \multicolumn{1}{c}{ Pekerjaan } & $\begin{array}{c}\text { Jumlah } \\
\text { (orang })\end{array}$ & $\begin{array}{c}\text { Presentase } \\
(\%)\end{array}$ \\
\hline 1 & Mahasiswa & 50 & 50 \\
2 & Pelajar & 3 & 3 \\
3 & Pegawai/karyawan & 14 & 14 \\
4 & Wiraswasta & 13 & 13 \\
5 & Petani & 2 & 2 \\
6 & Tidak bekerja & 18 & 18 \\
\hline & Jumlah & 100 & 100,0 \\
\hline
\end{tabular}

Data primer, diolah tahun 2021
Berdasarkan data dari tabel 4 dapat diketahui bahwa sebagian besar pelanggan warung kopi Cak Kebo bekerja sebagai mahasiswa sebanyak 50 orang $(50 \%)$.

\section{Deskripsi Variabel Penelitian}

Berikut ini akan ditampilkan hasil olahan data primer yang merupakan gambaran dari hasil penelitian berdasarkan jawaban responden mengenai analisis pengaruh strategi bauran pemasaran jasa di warung kopi Cak Kebo berdasarkan strategi promosi melalui media sosial dengan 4 pertanyaan indikator, kualitas pelayanan dengan 3 pertanyaan, word of mouth dengan 3 pertanyaan, dan loyalitas pelanggandengan 4 pertanyaan indikator, jadi total terdapat 14 pertanyaan. Hasil data tersebut diolah menggunakan SPSS 25.

\section{Strategi Promosi Melalui Media Sosial (X1)}

Strategi promosi melalui media sosial diukur dengan menggunakan tiga indicator. Hasil tabulasi dapat dilihat pada tabel sebagai berikut:

Tabel 5. Frekuensi Pernyataan Responden Terhadap Strategi Promosi Melalui Media Sosial

\begin{tabular}{cccccc}
\hline \multicolumn{5}{c}{ Total pernyataan } \\
\hline 1 & 4 & 13 & 36 & 46 & 100 \\
$(1 \%)$ & $(4 \%)$ & $(13 \%)$ & $(36 \%)$ & $(46 \%)$ & $(100 \%)$ \\
- & 7 & 11 & 42 & 40 & 100 \\
& $(7 \%)$ & $(11 \%)$ & $(42 \%)$ & $(40 \%)$ & $(100 \%)$ \\
1 & 5 & 21 & 44 & 29 & 100 \\
$(1 \%)$ & $(5 \%)$ & $(21 \%)$ & $(44 \%)$ & $(29 \%)$ & $(100 \%)$ \\
\hline \multicolumn{7}{c}{$100(100 \%)$} \\
\hline
\end{tabular}

Data primer, diolah tahun 2021

Pada pernyataan pertama, mayoritas responden menyatakan bahwa mereka mengikuti update perkembangan mengenai warung kopi Cak Kebo melalui media sosial. Sebanyak 46 orang atau $46 \%$ responden telah menjawab sangat setuju, 36 orang atau $36 \%$ menjawab setuju, dan 13 orang atau $13 \%$ menjawab cukup. Dari keseluruhan responden, sebanyak 4 orang menjawab tidak setuju, serta 1 orang menjawab sangat tidak setuju. Mayoritas pelanggan mengetahui dan mengeikuti perkembangan dan event yang ditawarkan oleh warung kopi Cak Kebo melalui media sosial.

Berkaitan dengan poin kedua, mayoritas responden menyatakan mereka sering melihat promosi yang dilakukan oleh warung kopi Cak Kebo di media sosial. Dapat dilihat dari frekuensi pernyataan 40 orang menjawab sangat setuju, 42 orang mejawab setuju, 11 orang menjawab cukup, serta sebanyak $7 \%$ menjawab tidak setuju. Dengan hasil lebih dari $40 \%$ dari mereka menjawab sangat setuju menunjukan bahwa warung kopi Cak Kebo selalu konsisten dalam memberikan promosi melalui media sosial.

Untuk pertanyaan ketiga, mayoritas responden menyatakan karyawan warung kopi Cak Kebo berpenampilan rapi dan sopan. Dapat dilihat dari frekuensi pernyataan 29 orang menjawab sangat setuju, 44 orang atau $44 \%$ mejawab setuju, 21 orang atau $21 \%$ 
menjawab cukup. Selain itu, sejumlah 5 responden memberikan jawaban berupa tidak setuju dan sebanyak $1 \%$ sisanya menjawab sangat tidak setuju.

\section{Kualitas Pelayanan (X2)}

Kualitas pelayanan diukur dengan menggunakan lima indikator yaitu Bukti langsung, Keandalan, Ketanggapan, Jaminan, dan Empati. Hasil tabulasi secara deskriptif dapat dilihat pada tabel sebagai berikut:

Tabel 6. Frekuensi Pernyataan Responden Terhadap

\begin{tabular}{cccccc}
\multicolumn{5}{c}{ Kualitas Pelayanan } \\
\hline- & 1 & 15 & 53 & 31 & 100 \\
& $(1 \%)$ & $(15 \%)$ & $(53 \%)$ & $(31 \%)$ & $(100 \%)$ \\
- & 1 & 11 & 44 & 44 & 100 \\
& $(1 \%)$ & $(11 \%)$ & $(44 \%)$ & $(44 \%)$ & $(100 \%)$ \\
- & - & 16 & 38 & 46 & 100 \\
& & $(16 \%)$ & $(38 \%)$ & $(46 \%)$ & $(100 \%)$ \\
- & 1 & 14 & 44 & 41 & 100 \\
& $(1 \%)$ & $(14 \%)$ & $(44 \%)$ & $(41 \%)$ & $(100 \%)$ \\
- & - & 18 & 38 & 44 & 100 \\
& & $(18 \%)$ & $(38 \%)$ & $(44 \%)$ & $(100 \%)$
\end{tabular}

$100(100 \%)$

Data primer, diolah tahun 2021

Dapat dilihat dari frekuensi pernyataan pertama 31 reponden menjawab sangat setuju dan sebanyak 53 orang menjawab setuju. Selain itu, sebanyak 15 orang menjawab cukup dan 1 responden menjawab tidak setuju. Dengan mayoritas responden yang menyatakan bahwa warung kopi Cak Kebo memiliki sarana, prasarana dan tempat yang memadai melebihi $80 \%$, dapat dikatakan, untuk kalangan mahasiswa sebagai pangsa pasar utama, warung kopi Cak Kebo memiliki bukti fisik berupa sarana yang memadai untuk menunjang mahasiswa.

Berkaitan dengan pertanyaan kedua yaitu warung kopi Cak Kebo mampu memberikan pelayanan pada pelanggan dengan cepat, mayoritas responden menjawab sangat setuju dan setuju dengan masing-masing berjumlah 44 orang, dan 11 orang menjawab cukup. Selebihnya menjawab tidak setuju dengan jumlah 1 orang.

Pada poin ketiga, 84\% responden sepakat menjawab bahwa warung kopi Cak Kebo tanggap dalam mendengar, menerima, dan bertindak dalam menyelesaikan keluhan dari pelanggan. Selebihnya sebanyak 16 orang menjawab cukup.

Adapun untuk pernyataan keempat, sebanyak 44 orang lebih memilih menjawab setuju untuk pertanyaan dapat menciptakan rasa aman saat ngopi pada pelanggan. Selain itu sebanyak $41 \%$ memilih menjawb sangat setuju, 14\% menjawab cukup, dan 1 orang menjawab tidak setuju.

Untuk pernyataan terakhir yaitu kelima, lebih dari $80 \%$ responden sejutu dengan peneliti yaitu memberikan pelayanan pada pelanggan selalu mengedepankan perhatian dan kesopanan dalam memberikan informasi, dengan rincian sebanyak 44 orang memilih sangat setuju dan 38 responden memilih setuju, sisanya lebik memilih cukup sebagai pilihan netral.

Berdasarkan dari penjabaran data frekuensi pada tabel 6 , secara umum kualitas pelayanan berperan penting terhadap kegiatan pelayanan kepada pelanggan selama melakukan pembelian. Artinya warung kopi Cak Kebo telah memberikan pelayanan yang memuaskan kepada pelnggan dan kesigapan para pekerja yang selalu siap membantu, memberikan keramahan, dan dan sopan dalam setiap melayani pelanggan.

\section{Word Of Mouth (X3)}

Word of mouth diukur dengan menggunakan 3 indikator dan secara deskriptif dapat dilihat pada tabel sebagai berikut:

Tabel 7. Frekuensi Pernyataan Responden Terhadap Word of Mouth

Total pernyataan

\begin{tabular}{cccccc}
- & 5 & 25 & 48 & 22 & 100 \\
& $(5 \%)$ & $(25 \%)$ & $(48 \%)$ & $(22 \%)$ & $(100 \%)$ \\
- & 5 & 25 & 48 & 22 & 100 \\
& $(5 \%)$ & $(25 \%)$ & $(48 \%)$ & $(22 \%)$ & $(100 \%)$ \\
- & 2 & 22 & 48 & 28 & 100 \\
& $(2 \%)$ & $(22 \%)$ & $(48 \%)$ & $(28 \%)$ & $(100 \%)$ \\
\hline \multicolumn{5}{c}{$100(100 \%)$}
\end{tabular}

Data primer, diolah tahun 2021

Pada pertanyaan pertama, mayoritas responden menyatakan sering mendengar nama warung kopi Cak Kebo didalam percakapan sehari-hari. Dapat dilihat dari frekuensi pernyataan 22 orang menjawab sangat setuju, 48 orang menjawab setuju, 25 orang menjawab cukup, dan 5 orang menjawab tidak setuju.

Berkaitan dengan pernyataan kedua, mayoritas responden menjawab setuju bahwa para responden sering mendapat rekomendasi untuk warung kopi Cak Kebo dari orang lain yaitu sebanyak 48 orang. Selain itu, 22 orang mejawab sangat setuju, dan selebihnya menjawab menjawab cukup dan tidak setuju masing-masing berjumlah 25 dan 5 orang.

Pada pernyataan ketiga, kebanyakan responden sering menerima berita positif warung kopi Cak Kebo dari orang lain. Dapat dilihat dari jumlah responden yang menjawab setuju lebih dari 40 orang. Dengan tambahan sebanyak 28 orang yang menjawab sangat setuju, menghasilkan total 76 orang yang sepakat hal tersebut. Selain itu, sebanyak 22 orang lebih memilih menjawab netral dan sisanya memilih tidak setuju.

\section{Loyalitas Pelangggan (Y)}

Loyalitas pelangggan diukur dengan menggunakan 4 indikator. Hasil dari tabulasi pada aplokasi SPSS versi 25 secara deskriptif dapat dilihat pada tabel 8 .

Pada pernyataan pertama, yaitu tidak terpengaruh dengan penawaran dari warung kopi Cak Kebo, mayoritas responden menjawab setuju dengan pertanyaan ini. Sebesar 42 orang dan ditambah dengan sebanyak 18 orang yang menjawab sangat setuju, merupakan nilai 
yang besar. Hal ini dapat diinkasikan sebagai pelanggan warung kopi Cak Kebo telah sangat loyal pada warung ini.

Menurut hasil tabulasi pertanyaan kedua, para responden rata-rata menjawab sangat setuju untuk menjadikan warung kopi Cak Kebo sebagai pilihan utama tempat nongkrong responden. Dapat dilihat dari frekuensi, selain menjawb sangat setuju dan setuju, Sebagian kecil responden menjawab cukup sebesar 22 orang dan menjawab tidak setuju sebesar 6 orang.

Tabel 8. Frekuensi Pernyataan Responden Terhadap Loyalitas Pelangggan

\begin{tabular}{cccccc}
\hline \multicolumn{5}{c}{ Total pernyataan } \\
\hline- & 1 & 39 & 42 & 18 & 100 \\
- & 6 & 22 & 35 & 37 & 100 \\
& $(6 \%)$ & $(22 \%)$ & $(35 \%)$ & $(37 \%)$ & $(100 \%)$ \\
- & 1 & 14 & 47 & 38 & 100 \\
& $(1 \%)$ & $(14 \%)$ & $(47 \%)$ & $(48 \%)$ & $(100 \%)$ \\
\hline
\end{tabular}

Data primer, diolah tahun 2021

Pada pernyataan ketiga, sebanyak 85 orang responden menyatakan telah menyarankan kepada orang lain untuk datang ke warung kopi Cak Kebo. Selain itu, sebesar 14 orang bersikap pasif dengan menjawab netral atau cukup.

Berdasarkan dari penjabaran data frekuensi pada tabel 8, dapat disimpulkan bahwa secara umum loyalitas pelangggan berperan penting terhadap proses pelayanan pelangggan dimana pelanggan benar-benar membeli karena yakin pada kualitasnya dan produk sesuai apa yang pelanggan diinginkan di warung kopi Cak Kebo, dan merasa puas dengan menggunakan jasa pelayanan di warung kopi Cak Kebo.

\section{Pengujian Hipotesis}

Uji $\mathrm{T}$ dikenal dengan uji parsial, yaitu untuk menguji bagaimana pengaruh masing-masing variabel bebasnya secara sendiri-sendiri terhadap variabel terikatnya. Uji ini dapat dilakukan dengan mambandingkan t hitung dengan $\mathrm{t}$ tabel atau dengan melihat kolom signifikansi pada masing-masing $\mathrm{t}$ hitung. Berikut hasil $\mathrm{Uji} \mathrm{T}$ dengan aplikasi SPSS.

Tabel 9. Hasil Pengujian Hipotesis dengan Uji T

\begin{tabular}{ll}
\hline Model & Sig \\
\hline (Constant) & .003 \\
jumlah X1 & .083 \\
jumlah X2 & .016 \\
jumlah X3 & .034 \\
\hline
\end{tabular}

Data primer, diolah tahun 2021

Cara pengambilan keputusan dengan metode ini adalah jika nilai sig. $<0,05$ pada Tabel coeffients maka variabel $\mathrm{X}$ secara parsial berpengaruh terhadap variable Y. Dari Tabel 9 didapat hasil uji strategi promosi melalui media sosial mempunyai nilai signifikansi hitung sebesar 0,083 dan lebih besar dari 0,05 yang berarti bahwa hipotesis strategi promosi melalui media sosial tidak mempunyai pengaruh signifikan terhadap loyalitas pelangggan ditolak. Hal ini juga menunjukkan bahwa strategi promosi melalui media sosial tidak mempengaruhi terhadap loyalitas pelangggan yang berarti semakin baik strategi promosi melalui media sosial tidak akan berdampak pada semakin baiknya loyalitas pelangggan.

Hasil uji kualitas pelayanan mempunyai nilai signifikansi hitung sebesar 0,016 dan lebih besar dari 0,05 yang berarti bahwa hipotesis kualitas pelayanan mempunyai pengaruh signifikan terhadap loyalitas pelangggan ditolak. Hal ini juga menunjukkan bahwa kualitas pelayanan mempengaruhi terhadap loyalitas pelangggan yang berarti semakin baik kualitas pelayanan akan berdampak pada semakin baiknya loyalitas pelangggan.

Hasil uji word of mouth mempunyai nilai signifikansi hitung sebesar 0,034 dan lebih kecil dari 0,05 yang berarti bahwa hipotesis word of mouth mempunyai pengaruh signifikan terhadap loyalitas pelangggan diterima. Hal ini juga menunjukkan bahwa word of mouth mempengaruhi terhadap loyalitas pelangggan yang berarti semakin baik word of mouth akan berdampak pada semakin tingginya loyalitas pelangggan.

\section{Pembahasan}

Berdasarkan hasil pengujian secara sistematik, didapat hasil pengujian ini membuktikan bahwa strategi promosi melalui media sosial (X1) mempunyai nilai signifikansi hitung sebesar 0,083 dan lebih besar dari 0,05 yang berarti bahwa hipotesis strategi promosi melalui media sosial tidak mempunyai pengaruh signifikan terhadap loyalitas pelangggan ditolak. Hasil ini berbeda dengan hasil Penelitan yang dilakukan oleh Arifin dan Hufron (2019) yang menyimpulkan bahwa promosi penjualan berpengaruh langsung secara signifikan terhadap loyalitas pelanggan. Pengujian secara statistik ini membuktikan bahwa kesediaan dan siap membantu, keramahan untuk membantu, karyawan berpenampilan rapi dan sopan, simpatik dan ramah dalam pelayanan lebih menarik pelanggan untuk tetap datang. Artinya bahwa tidak ada pengaruh strategi promosi melalui media sosial terhadap loyalitas pelangggan. pengujian ini dapat tergambar pada kurangnya optimalnya penggunaan Instagram sebagai media promosi. Kurangnya tenaga ahli dalam penenetuan konten promosi, membuat perkembangan promosi online warung ini stagnan.

Hasil pengujian pengaruh kualitas pelayanan (X2) terhadap loyalitas pelangggan, membuktikan bahwa kualitas pelayanan (X2) mempunyai nilai signifikansi hitung sebesar 0,016 dan lebih kecil dari 0,05 yang berarti bahwa hipotesis kualitas pelayanan (X2) mempunyai pengaruh signifikan terhadap loyalitas pelangggan dan diterima. Pengujian secara statistik ini membuktikan bahwa kecepatan dalam proses transaksi pembayaran, pelayanan dalam pembelian jasa, tempat yang memadai, dan pelayanan yang diberikan oleh pekerja. Artinya bahwa ada pengaruh kualitas pelayanan (X2) terhadap loyalitas pelangggan.

Hasil ini sejalan dengan hasil dari penelitian yang dilakukan Hasanuddin (2019) yang meneliti tentang 
pengaruh kualitas produk, kualitas pelayanan dan kepercayaan pelanggan terhadap loyalitas pelanggan di kedai kopi mr beard coffee Jl, Saxophone No. 47 Tunggul Wulung Lowokwaru Malang menyimpulkan bahwa antara variabel produk, kualitas layanan dan kepercayaan pelanggan membuktikan mempunyai pengaruh signifikan secara parsial terhadap loyalitas pelanggan pada Kedai Kopi Mr Beard Coffee. Sebagai usaha yang bergerak dibidang jasa, warung kopi Cak Kebo ini telah cukup serius untuk memperhatikan kualitas pelayanan yang dilakukan. Sebagai contoh yaitu pemberlakuan evaluasi rutin dalam kurun waktu enam bulan sekali. Para pemilik juga mengadakan pelatihan dan pembinaan karyawan agar selalu memperhatikan kualitas pelayanan yang mereka berikan.

Hasil pengujian word of mouth (X3) terhadap loyalitas pelangggan dalam penelitian ini membuktikan bahwa word of mouth (X3) mempunyai nilai signifikansi hitung sebesar 0,034 dan lebih kecil dari 0,05 yang berarti bahwa hipotesis word of mouth (X3) mempunyai pengaruh signifikan terhadap loyalitas pelangggan diterima.

Pengujian secara statistik ini mendukung hasil Penelitian yang dilakukan oleh Yusfita dan Yulianto (2018) menyimpulkan bahwa variabel word of mouth berpengaruh signifikan secara parsial terhadap loyalitas Pelanggan. Hal ini dapat diartikan bawah variabel word of mouth berdampak positif secara parsial terhadap Loyalitas Pelanggan. Penelitian ini menggunakan metode regresi linier. warung kopi Cak Kebo ini lebih menekan promosi melalui mulut ke mulut sebagai strtegi utama mereka. Dengan proses berantai yang berawal dari ajakan seorang pelanggan terhadap konsumen baru hingga konsumen tersebut melakukan pembelian berulang.

\section{Simpulan dan Implikasi Penelitian}

Dari analisis yang telah dilakukan pada penelitian ini, maka dapat ditarik kesimpulan bahwa strategi promosi melalui media sosial (X1) tidak berpengaruh secara parsial terhadap loyalitas pelanggan(Y). kualitas pelayanan (X2) berpengaruh secara parsial terhadap loyalitas pelanggan (Y). word of mouth (X3) berpengaruh secara parsial terhadap loyalitas pelanggan (Y).

Kualitas pelayan lebih mempengaruhi loyalitas pelanggan pada saat para pelanggan melakukan pembelian jasa. Mengingat tempat yang memadai dan keramahan pekerja membuat pelayanan yang dilakuan menjadi optimal. Pelayan yang membuat pelanggan lebih mementingkan hasil yang memuaskan.

\section{Referensi}

Amalya, Indah. 2016. Pengaruh Relationship Marketing Terhadap Kepuasan Dan Loyalitas Pelanggan Klinik Kecantikan Larissa Aesthetic Center Cabang Jember. Skripsi. Fakultas Ekonomi Dan Bisnis Universitas Jember.

Agusty, Ferdinand. 2014. Metode Penelitian Manajemen Edisi 5. Semarang: Badan Penerbit Universitas Diponegoro.
Alma, B. 2014. Manajemen Pemasaran dan Pemasaran Jasa. Bandung: Alfabeta.

Anggita, Kholid. 2015. Pengaruh Customer Relationship Management Terhadap Kepuasan Pelanggan dan Loyalitas Pelanggan. Jurnal Fakultas Ilmu Administrasi Universitas Brawijaya Malang.

Arikunto S. 2006. Prosedur Penelitian Suatu Pendekatan Praktek. Jakarta: Rineka Cipta.

Asriel, Azis. 2016. Pengaruh Kualitas Pelayanan terhadap Kepercayaan dan Loyalitas Konsumen (Studi kasus pada pelanggan jasa pengiriman paket PT. POS Indonesia)(Persero). Skripsi. Universitas Negeri Yogyakarta.

Ayu, Prof. Dr. Hatane. 2015. Pengaruh Customer Relationship Management (CRM) Terhadap Customer Satisfaction Dan Customer Loyalty Pada Pelanggan Sushi Tei Surabaya. Jurnal Fakultas Ekonomi Universitas Kristen Petra Surabaya.

Bony, Edy. 2017. Pengaruh Customer Relationship Management Terhadap Kepuasan Pelanggan Dan Loyalitas Pelanggan (Survei pada Pelanggan GraPARI Telkomsel di Kota Malang). Jurnal Fakultas Ilmu Administrasi Universitas Brawijaya Malang.

Darwin, S. 2014. Analisis Pengaruh Kualitas Layanan Terhadap Loyalitas Pelanggan Dengan Kepuasan Dan Kepercayaan Pelanggan Sebagai Variabel Intervening Pada Asuransi Jiwa Manulife Indonesia - Surabaya. Jurnal Manajemen. 2. (1).

Debora, Lisbeth, Rotinsulu. 2017. Pengaruh Layout, Fasilitas, Dan Kualitas Pelayanan Terhadap Kepuasan Pelanggan Pada Matahari Departement Store Mega Mall Manado. Jurnal Fakultas Ekonomi Dan Bisnis Jurusan Manajemen Universitas Sam Ratulangi Manado.

Dulkhatif. 2016. Pengaruh Kualitas Pelayanan, Kepuasan Pelanggan dan Lokasi Terhadap Loyalitas Pelanggan Pada Penyedia Jasa Internet Study PT Noken Mulia Tama Semarang. Jurnal Of Management. 2. (2).

Fanny. 2016. Pengaruh Harga, Citra Merek, Dan Word Of Mouth Terhadap Kepuasan Konsumen. Jurnal Sekolah Tinggi Ilmu Ekonomi Indonesia (STIESIA) Surabaya.

Ghozali, Imam. 2005. Analisis Multivariate SPSS. Semarang: Universitas Diponegoro.

Ghozali Imam. 2013. Aplikasi Analisis Multivariate Dengan Program IBM SPSS 21. Edisi 7. Semarang: Universitas Diponegoro.

Grifin, J. 2005. Customer Loyalty. Edisi Revisi. Jakarta : Erlangga Gujarati Damodar. 2005. Ekonometrika Dasar. Jakarta: Erlangga.

Jannah, I. F. 2016. Pengaruh Kualitas Produk dan Harga Terhadap Loyalitas Konsumen Melalui Kepuasan Konsumen Produk Air Minum Dalam Kemasan (AMDK) Galon Merek Aqua Pada Mahasiswa Universitas Jember. Skripsi. Universitas Jember.

Kendri. 2018. Pengaruh strategi promosi dan loyalitas pelanggan terhadap keputusan pembelian. 30(1).

Kotler, P. 2002. Manajemen Pemasaran. Jilid 1. Edisi 
Milenium. Jakarta: Prehalindo.

Kotler, P. 2007. Manajemen Pemasaran di Indonesia: Analisis Perencanaan, Implementasi dan Pengendalian. Jakarta: Salemba Empat.

Kotler, P \& Keller, K. 2009. Manajemen Pemasaran. Edisi Ketiga Belas, Jilid 1. Jakarta: Erlangga

Lupiyoadi, H. 2006. Manajemen Pemasaran Jasa. Edisi 2. Jakarta: Salemba Empat.

Mahadewi, A. G. 2018. Pengaruh Bauran Pemasaran Pariwisata Dan Kualitas Pelayanan Pariwisata Melalui Kepuasan Wisatawan Terhadap Minat Berkunjung Kembali (Studi Pada Destinasi Grand Watu Dodol (Gwd) Kabupaten Banyuwangi). Skripsi. Universitas Jember.

Mongi, Lidya. 2013. Kualitas Produk, Strategi Promosi Dan Harga Pengaruhnya Terhadap Keputusan Pembelian Kartu Simpati Telkomsel Di Kota Manado Jurnal EMBA Vol.1 No.4 Desember 2013, Hal. 2336-2346. ISSN 2303-1174.

Nurfina, O. 2016. Analisis Pengaruh E-Commerce Strategy, Service Performance Terhadap Loyalitas Pelanggan dan Kepuasan Pelanggan Sebagai Variabel Intervening. Journal Of Management. 2.(2).

Pramana, IGY. 2016. Pengaruh Kualitas Pelayanan Terhadap Kepercayaan Nasabah Dan Loyalitas Nasabah Bank Mandiri Cabang Veteran Denpasar Bali. E-Jurnal Manajemen Unud, 5 (1): 706-733.

Prayitno, Dwi. 2010. Paham Analisis Data Statistik Dengan SPSS. Yogyakarta : Mediakom.

Rezki, M.A. 2019. Efektivitas Strategi Promosi Produk Kopi Lokal Di Rumah Kopi Ranin. Jurnal Komunikasi Pembangunan Februari 2019, Volume 17. No. 1 eISSN 2442-4102.

Sugiyono. 2014. Metode Penelitian Kuantitatif, Kualitatif, dan Kombinasi (Mixed Methods). Bandung: Alfabeta.

Sugiyono. 2012. Statistik Untuk Penelitian. Bandung: Alfabeta.

Tjiptono, Fandy. 2012. Strategi Pemasaran. Yogyakarta: Andi. 